\title{
Profiling of Phytochemicals in Tissues from Sclerocarya birrea by HPLC-MS and Their Link with Antioxidant Activity
}

\author{
Daniela Russo, ${ }^{1,2}$ Owen Kenny, ${ }^{1}$ Thomas J. Smyth, ${ }^{1}$ Luigi Milella, ${ }^{2}$ Mohammad B. Hossain, \\ Moussoukhoye Sissokho Diop, ${ }^{3}$ Dilip K. Rai, ${ }^{1}$ and Nigel P. Brunton ${ }^{4}$ \\ ${ }^{1}$ Department of Food Biosciences, Teagasc Food Research Centre, Ashtown, Dublin 15, Ireland \\ ${ }^{2}$ Department of Biology, University of Basilicata, V.le dell'Ateneo Lucano, 85100 Potenza, Italy \\ ${ }^{3}$ Faculte des Sciences et Techniques, Universite Cheikh Anta Diop de Dakar, BP 5005, Dakar-Fann, Senegal \\ ${ }^{4}$ School of Agriculture and Food Science, University College Dublin, Dublin 4, Ireland \\ Correspondence should be addressed to Dilip K. Rai; dilip.rai@teagasc.ie
}

Received 27 March 2013; Accepted 29 April 2013

Academic Editors: R. F. D. Nascimento, T. Oi, Y. Qiu, and Y. Uesawa

Copyright (C) 2013 Daniela Russo et al. This is an open access article distributed under the Creative Commons Attribution License, which permits unrestricted use, distribution, and reproduction in any medium, provided the original work is properly cited.

\begin{abstract}
High performance liquid chromatography-tandem mass spectrometry (HPLC-MS/MS) was employed to investigate the differences in phytochemicals in roots, bark, and leaf of Sclerocarya birrea (marula) for methanol and water extracts that exhibited the best antioxidant activities. As many as 36 compounds were observed in the extracts of these tissues of which 27 phenolic compounds were tentatively identified. The HPLC-MS/MS results showed flavonoid glycosides were prominent in leaf extracts while the galloylated tannins were largely in bark and root extracts. Four flavonoid glycosides that were reported for the first time in the marula leaf have been identified. The HPLC-MS/MS studies also illustrated different degrees (highest degree $=3$ ) of oligomerisation and galloylation of tannins in the bark and root extracts.
\end{abstract}

\section{Introduction}

Sclerocarya birrea (A. Rich.) Hochst, more commonly known as marula, is taxonomically derived from the Anacardiaceae plant family. It is an indigenous, fruit-bearing tree of subSaharan Africa [1]. It grows mostly at low altitudes and can reach up to $20 \mathrm{~m}$ in height and $1.2 \mathrm{~m}$ in diameter [2]. Traditionally, marula has multiple uses; the fruits are eaten or processed to make beer and jam, the kernels are eaten or their oils extracted, the leaves are used as forage for livestock, and the wood is carved into utilitarian items such as spoons and plates [2]. The marula tree has been the subject of numerous chemical, biological, and environmental investigations since 1906 [3] and has been identified as one of five fruit tree species that should be integrated in the domestication process in African farming system $[4,5]$. This is due to its use as source of food and medicine in rural communities and its potential to generate income through the sale of its derivates. The bark, leaves, and roots of Sclerocarya birrea (S. birrea)have attracted attention because they have been traditionally used to treat an assortment of human ailments such as dysentery, fevers, malaria, diarrhea, stomach ailments, rheumatism, sore eyes, gangrenous rectitis, infertility, headaches, toothache, and body pains $[6,7]$. As a result, extracts of this plant have been reported to possess antioxidant, antibacterial, antifungal, astringent anticonvulsant [8-10], antihyperglycemic, anti-inflammatory [11], and antiatherogenic properties [12]. Several of these properties could be attributed to the high content of polyphenols and its antioxidant activity [13-16]. As a result of their high antioxidant activities, extracts from $S$. birrea could also be used to control theoxidation of unsaturated lipids in foods, which not only lead to flavour [17] and colour deterioration [18] but can also lower nutritional value and is associated with negative health effects such as increased risk of heart disease and cancer in humans [19]. Previous studies involving S. birrea have detected the presence of 11 phenolic compounds in leaf extracts using HPLC-UV and HPLC-ESI/MS [13] and also in pulp extracts by HPLC-UV/Vis detection [15]. Only one previous study has investigated the phenolic composition of the bark, where 
NMR analysis identified the presence of a catechin derivate [20]. In addition, it has been reported that bark from $S$. birrea contains a significant amount of high molecular weight tannins $[16,21]$. Condensed tannins, such as procyanidins, have attracted increasing attention in the fields of nutrition and medicine due to their potential health benefits observed in vitro and in vivo. For instance, procyanidin oligomers have been shown to have potent antioxidant activity and the ability to scavenge reactive oxygen and nitrogen species $[22,23]$. However, no study to date has attempted to quantify the relative contribution of high and low molecular weight polyphenols to the total in vitro antioxidant activity of $S$. birrea. In the present study, we investigated a polyphenol rich crude extract that has been fractionated into high and low molecular weight components. The relative phenolic content and antioxidant activity of various crude and dialysed extracts from three different parts of S. birrea, bark, leaf, and root, were determined. Antioxidant extracts were selected for qualitative analysis, by means of HPLC-ESI-MS/MS, based on their relative in vitro antioxidant activities.

\section{Materials and Methods}

2.1. Samples and Chemicals. Fresh leaves bark and roots of S. birrea were collected from Dakar region in Senegal in September 2010. For the extraction, analytical grade n-hexane, chloroform $\left(\mathrm{CHCl}_{3}\right)$, methanol $(\mathrm{MeOH})$, ethylacetate, and water were acquired from Carlo Erba Reagents (Milan, Italy), while 2,2-diphenyl-1-picrylhydrazyl (DPPH), ferric chloride $\left(\mathrm{FeCl}_{3} * 6 \mathrm{H}_{2} \mathrm{O}\right)$, hydrochloric acid $(\mathrm{HCl})$, 2,4,6-Tris(2-pyridil)-striazine (TPTZ), sodium acetate, FolinCiocalteu phenol reagent, sodium carbonate, Trolox, HPLC grade acetonitrile, methanol, formic acid $(\mathrm{HCOOH})$, and water along with leucine-enkephalin, gallic acid, catechin, epicatechin, epicatechin-3-O-gallate, epigallocatechin-3-Ogallate, quercetin-3-O-arabinoside, quercetin-3-O-rhamnoside, quercetin-3-O-glucoside, and procyanidin B2, were purchased from Sigma-Aldrich (Arklow, Co., Wicklow, Ireland).

2.2. Extraction and Fractionation Based on Polarity and Molecular Size. The different parts of the plant, which were carefully cleaned removing foreign particles, were cut into small pieces and air-dried at room temperature. Leaves were powdered using a pestle and mortar, while the bark and roots of $S$. birrea were further broken up using a pestle and mortar. Samples of S. birrea bark, leaves, and roots weighing 215,150 , and $160 \mathrm{~g}$, respectively, were defatted using 5 volumes $(\mathrm{v} / \mathrm{w})$ of $\mathrm{n}$-hexane and extracted with $\mathrm{CHCl}_{3}$, $\mathrm{CHCl}_{3}: \mathrm{MeOH}(9: 1)$, and $\mathrm{MeOH}$, at room temperature, in amber bottles over 6 days. The bottles were periodically shaken and the solvent replenished at $48 \mathrm{hr}$ intervals. Each solvent extract was filtered through cellulose filter paper (17$25 \mu \mathrm{m}$ ) and concentrated using a rotary evaporator, under reduced pressure, at $37^{\circ} \mathrm{C}$. All extracts were weighed and stored in the dark at $4^{\circ} \mathrm{C}$.

Each methanol extract was further partitioned into hydrophobic and hydrophilic fractions using water and ethylacetate exhaustively using a separating funnel. The water fractions were lyophilized with the aid of a freeze dryer, while the ethylacetate fractions were concentrated using a rotary evaporator. The ethylacetate fractions were weighed and stored in the dark at $4^{\circ} \mathrm{C}$. Dialysis tubing, with a molecular weight cut-off of $3.5 \mathrm{kDa}$ (Fisher Scientific Ltd., Loughborough, Leicestershire, UK), was used to separate metabolites present in each water fraction into low molecular weight $(<3.5 \mathrm{kDa})$ and high molecular weight $(>3.5 \mathrm{kDa})$ extracts. Each of the $<3.5 \mathrm{kDa}$ and $>3.5 \mathrm{kDa}$ dialysed extracts was lyophilized to dryness. The weights of the lyophilised extracts were recorded and stored in the dark at $4^{\circ} \mathrm{C}$ (Table 1).

\subsection{Free Radical Scavenging Activity by DPPH Method. A} modified version of the DPPH assay, with Trolox as a standard, was used to measure antioxidant activity [24]. Briefly, $100 \mu \mathrm{L}$ of various concentrations (stock solution of $2 \mathrm{mg} / \mathrm{mL}$ ) of the extract or Trolox were added to $100 \mu \mathrm{L}$ of a methanol solution of DPPH $(0.0476 \mathrm{mg} / \mathrm{mL})$ in a 96 -well plate. The plate was incubated at room temperature for $30 \mathrm{~min}$ in the dark. The absorbance of the mixture was measured at $515 \mathrm{~nm}$ against the blank $(\mathrm{MeOH})$ using a plate reader (FLUOstar Omega, Ortenberg, Germany).

2.4. Ferric Reducing Antioxidant Power (FRAP) Assay. The FRAP assay was carried out as described by Stratil et al. with slight modifications [25]. The FRAP reagent was prepared by mixing $38 \mathrm{mM}$ sodium acetate anhydrous buffer in distilled water, $\mathrm{pH} 3.6$, with $20 \mathrm{mM} \mathrm{FeCl}_{3} * 6 \mathrm{H}_{2} \mathrm{O}$ in distilled water and $10 \mathrm{mM}$ TPTZ in $40 \mathrm{mM} \mathrm{HCl}$ in a ratio of $10: 1: 1$. A $20 \mu \mathrm{L}$ of appropriately diluted sample extract and $180 \mu \mathrm{L}$ of FRAP reagent were mixed in a 96-well plate and incubated at $37^{\circ} \mathrm{C}$ for $40 \mathrm{~min}$ in the dark. In the case of the blank, $20 \mu \mathrm{L}$ methanol was added to $180 \mu \mathrm{L}$ FRAP reagent. The absorbance of the resulting solution was measured at $593 \mathrm{~nm}$ using a plate reader. Trolox, at concentrations ranging from $0.1 \mathrm{mM}-$ $0.4 \mathrm{mM}$, was used as a reference antioxidant standard. Each sample was performed in triplicate.

2.5. Total Phenolic Content (TPC). The TPC was determined using the Folin-Ciocalteu method as described by Singleton et al. [26]. Methanolic gallic acid solutions (10$200 \mathrm{mg} / \mathrm{L}$ ) were used as standards. In each replicate, $100 \mu \mathrm{L}$ of the appropriately diluted sample extract, $100 \mu \mathrm{L}$ methanol, $100 \mu \mathrm{L}$ Folin-Ciocalteu reagent, and $700 \mu \mathrm{L}$ sodium carbonate $(20 \% \mathrm{w} / \mathrm{v})$ were added together and vortexed. The mixture was incubated for $20 \mathrm{~min}$ in the dark at room temperature. After incubation, the mixture was centrifuged at 13,000 rpm for $3 \mathrm{~min}$. The absorbance of the supernatant was measured at $735 \mathrm{~nm}$ using a UV-Vis spectrophotometer. The experiment was carried out in triplicate for all extract samples and standard dilutions.

2.6. HPLC-ESI-MS/MS. The analysis was carried out using an Alliance 2695 HPLC system (Waters Corp., Milford, MA) coupled to a Q-Tof Premier mass spectrometer (Waters Corp., Micromass MS Technologies, Manchester, UK). The Q-Tof 
TABLE 1: Dry weight of the extracts and their fractions.

\begin{tabular}{|c|c|c|c|c|c|c|c|c|}
\hline \multirow[b]{2}{*}{$\begin{array}{l}\text { Name of the } \\
\text { plant }\end{array}$} & \multirow[b]{2}{*}{$\begin{array}{l}\text { Parts of the } \\
\text { plant }\end{array}$} & \multicolumn{7}{|c|}{ Extraction solvent } \\
\hline & & Hexane & Chloroform & Methanol & $\begin{array}{r}\text { Solvent based } \\
\text { methan }\end{array}$ & $\begin{array}{l}\text { titioning of the } \\
\text { tract }\end{array}$ & $\begin{array}{l}\text { Memb } \\
\text { of the } w\end{array}$ & $\begin{array}{l}\text { ialysis } \\
\text { xtract }\end{array}$ \\
\hline \multirow{6}{*}{ Marula } & \multirow{2}{*}{ Bark } & \multirow{2}{*}{$300 \mathrm{mg}$} & \multirow{2}{*}{$100 \mathrm{mg}$} & \multirow{2}{*}{$3600 \mathrm{mg}$} & Water & $3480 \mathrm{mg}$ & $<3.5 \mathrm{kDa}$ & $1090 \mathrm{mg}$ \\
\hline & & & & & Ethylacetate & $12.1 \mathrm{mg}$ & $>3.5 \mathrm{kDa}$ & $1560 \mathrm{mg}$ \\
\hline & \multirow{2}{*}{ Leaf } & \multirow{2}{*}{$350 \mathrm{mg}$} & \multirow{2}{*}{$500 \mathrm{mg}$} & \multirow{2}{*}{$900 \mathrm{mg}$} & Water & $263 \mathrm{mg}$ & $<3.5 \mathrm{kDa}$ & $110 \mathrm{mg}$ \\
\hline & & & & & Ethylacetate & $18.2 \mathrm{mg}$ & $>3.5 \mathrm{kDa}$ & $20 \mathrm{mg}$ \\
\hline & \multirow{2}{*}{ Root } & \multirow{2}{*}{$300 \mathrm{mg}$} & \multirow{2}{*}{$150 \mathrm{mg}$} & \multirow{2}{*}{$3000 \mathrm{mg}$} & Water & $2780 \mathrm{mg}$ & $<3.5 \mathrm{kDa}$ & $340 \mathrm{mg}$ \\
\hline & & & & & Ethylacetate & $19.6 \mathrm{mg}$ & $>3.5 \mathrm{kDa}$ & $1220 \mathrm{mg}$ \\
\hline
\end{tabular}

was equipped with a lockspray source with an internal reference compound (leucine-enkephalin) for accurate mass measurements. An Atlantis T3 C18 column (waters Corp., Milford, $\mathrm{MA} ; 2.1 \times 100 \mathrm{~mm}$ ) was used to separate the compounds. A binary mobile phase consisting of $0.5 \% \mathrm{HCOOH}$ (solvent A) and $0.5 \% \mathrm{HCOOH}$ in $50: 50 \mathrm{v} / \mathrm{v}$ acetonitrile:methanol (solvent B) was used. The gradient program was as follows: $0 \%-15 \% \mathrm{~B}$ in $1 \mathrm{~min}, 60 \%-40 \% \mathrm{~B}$ in $5 \mathrm{~min}, 50 \%-50 \% \mathrm{~B}$ in $2 \mathrm{~min}$, $30 \%-70 \% \mathrm{~B}$ in $6 \mathrm{~min}, 20 \%-80 \% \mathrm{~B}$ in $4 \mathrm{~min}$, and $80 \%-20 \% \mathrm{~B}$ in $7 \mathrm{~min}$. The flow rate was $0.2 \mathrm{~mL} / \mathrm{min}$. Electrospray mass spectra data were recorded in the negative ionization mode for a mass range from $\mathrm{m} / \mathrm{z} 100$ to 1000 . The capillary and cone voltage were set at $3 \mathrm{kV}$ and $30 \mathrm{~V}$, respectively, and the data were acquired using MassLynx version 4.1. The collision energy used for the MS/MS experiments ranged from $8 \mathrm{eV}$ to $40 \mathrm{eV}$ depending on the size of the molecular mass selected for the collision induced dissociation (CID).

2.7. Statistical Analysis. Analysis of variance (ANOVA, oneway) was used to find differences between the extracts studied. Means were compared by least significant difference (LSD) test, at a significance level $P=0.05$ using the Statgraphics software (version 2.1; Statistical Graphics Co., Rockville, USA).

\section{Results and Discussion}

3.1. Antioxidant Activity and Total Phenolic Content. The results of the two antioxidant assays for the 15 different extracts were broadly in agreement. This was reflected by the high Pearson's correlation coefficient value $(r=0.940)$ between both. In relation to each plant tissue under investigation, a common trend emerged, which showed that the dialysed and water extracts of the leaf, root, and bark had the highest antioxidant activities in each case (Table 2). Most notably, the root $<3.5 \mathrm{kDa}$ dialysed extract exhibited the highest FRAP $(220.41 \pm 4.655$ Trolox equivalent (TE) $\mathrm{g} / 100 \mathrm{~g}$ dry weight sample (DWS)) value. The DPPH radical scavenging activity of this extract also had a high value $(137.974 \pm 6.790 \mathrm{TE}$ g/100 g DWS $)$, though the highest activity reported for the DPPH assay was seen in the bark water crude extract (183.973 $\pm 7.029 \mathrm{TE}$ g/100 g DWS). The hexane and ethyl acetate extracts of the leaf, root, and bark recorded generally lower antioxidant activities than those of the water and methanolic extracts in this study. This indicated that the antioxidant compounds in marula were predominantly polar. A comparison of DPPH $\mathrm{IC}_{50}$ values between the lowest and highest antioxidant activity confirmed that the leaf hexane, bark ethyl acetate, and root hexane extracts had a significantly $(P<0.05)$ lower antioxidant potential than the leaf $<3.5 \mathrm{kDa}$ and water extracts of both the bark and roots.

In line with their high antioxidant activities, these $S$. birrea polar extracts also possessed a high total phenolic content (TPC). The TPC data of these extracts revealed a high degree of positive correlation with the results of both the DPPH (Pearson's correlation coefficient, $r=0.905$ ) and FRAP (Pearson's correlation coefficient, $r=0.855$ ) assays. Moyo et al. also reported that leaf, young stem, and opercula extracts from $S$. birrea had the highest antioxidant activity and possessed the highest phenolic content, thus indicating a strong relationship between phenolic content and antioxidant activity [27]. The root $>3.5 \mathrm{kDa}$ dialysed extract had the highest TPC value $(103.39 \pm 0.006$ gallic acid equivalent (GAE) g/100 g DWS), followed by the root $<3.5 \mathrm{kDa}$ dialysed extract $(101.586 \pm 0.009 \mathrm{GAE} g / 100 \mathrm{~g}$ DWS $)$. This could be due to the presence of high molecular weight polymeric polyphenols in these extracts $[16,21]$. The leaf hexane extract, as expected from the low antioxidant activity values, had the lowest TPC value $(10.00 \pm 0.01 \mathrm{GAE} g / 100 \mathrm{~g}$ DWS $)$. In the case of leaf extracts, the hydrophilic $<3.5 \mathrm{kDa}$ fractions had significantly higher TPC $(P<0.05)$ than the fractions of $>3.5 \mathrm{kDa}$. This might be due to greater relative abundance of low molecular weight unbound polar phenolic compounds in the leaf compared to the bark and root. Other authors have also reported that when a high level of structural polysaccharides are present in food, which could be the case for both the bark and the root extracts, a high proportion of polyphenols will be bound to these polysaccharides [28].

To date, the majority of studies on S. birrea have concentrated on the fruit and leaves [12, 13]. Mariod et al. investigated the phenolic content and antioxidant activity of $60 \%$ aqueous methanol extracts from leaf, bark and root of S. birrea and reported that the bark, and root extracts had higher phenolic content than the leaf extract [15], which is 
TABLE 2: Total phenol, FRAP, and DPPH radical-scavenging activities for various leaf, bark, and root crude and dialysed extracts of marula tree $\left(S\right.$. birrea). Values are expressed as means \pm standard deviations $(n=3)^{1}$.

\begin{tabular}{lcccc}
\hline Extract & TPC $($ GAE g/100 g DWS $)$ & FRAP $($ TE g/100 g DWS $)$ & DPPH IC $_{50}(\mu \mathrm{g} / \mathrm{mL})$ & DPPH $(\mathrm{TE} \mathrm{g} / 100 \mathrm{~g} \mathrm{DWS})$ \\
\hline Leaf hexane & $10.00 \pm 0.01^{\mathrm{a}}$ & $0.08 \pm 0.03^{\mathrm{a}}$ & $176.57 \pm 1.42^{\mathrm{e}}$ & $4.27 \pm 0.34^{\mathrm{a}}$ \\
Leaf ethylacetate & $18.29 \pm 0.02^{\mathrm{b}}$ & $8.02 \pm 0.76^{\mathrm{b}}$ & $76.63 \pm 5.31^{\mathrm{d}}$ & $9.82 \pm 0.69^{\mathrm{a}}$ \\
Leaf $<3.5 \mathrm{kDa}$ & $53.88 \pm 0.02^{\mathrm{e}}$ & $72.84 \pm 1.88^{\mathrm{e}}$ & $8.42 \pm 0.36^{\mathrm{ab}}$ & $89.20 \pm 3.95^{\mathrm{e}}$ \\
Leaf $>3.5 \mathrm{kDa}$ & $44.53 \pm 0.01^{\mathrm{d}}$ & $55.10 \pm 2.23^{\mathrm{d}}$ & $13.88 \pm 0.40^{\mathrm{b}}$ & $54.07 \pm 1.80^{\mathrm{c}}$ \\
Leaf Water & $45.35 \pm 0.001^{\mathrm{d}}$ & $56.10 \pm 2.20^{\mathrm{d}}$ & $12.23 \pm 0.24^{\mathrm{b}}$ & $61.36 \pm 1.19^{\mathrm{c}}$ \\
\hline Bark hexane & $48.43 \pm 0.02^{\mathrm{de}}$ & $88.12 \pm 8.09^{\mathrm{f}}$ & $9.91 \pm 0.59^{\mathrm{ab}}$ & $75.85 \pm 4.59^{\mathrm{d}}$ \\
Bark ethylacetate & $23.02 \pm 0.01^{\mathrm{bc}}$ & $23.33 \pm 1.19^{\mathrm{c}}$ & $26.12 \pm 3.09^{\mathrm{c}}$ & $28.30 \pm 3.20^{\mathrm{b}}$ \\
Bark $<3.5 \mathrm{kDa}$ & $100.17 \pm 0.01^{\mathrm{i}}$ & $216.64 \pm 8.40^{\mathrm{k}}$ & $5.11 \pm 0.10^{\mathrm{a}}$ & $146.86 \pm 2.72^{\mathrm{i}}$ \\
Bark $>3.5 \mathrm{kDa}$ & $69.66 \pm 0.003^{\mathrm{f}}$ & $102.46 \pm 5.49^{\mathrm{g}}$ & $5.95 \pm 0.50^{\mathrm{ab}}$ & $126.64 \pm 10.77^{\mathrm{g}}$ \\
Bark water & $90.33 \pm 0.03^{\mathrm{h}}$ & $197.34 \pm 5.58^{\mathrm{j}}$ & $4.08 \pm 0.16^{\mathrm{a}}$ & $183.97 \pm 7.03^{\mathrm{j}}$ \\
\hline Root hexane & $26.53 \pm 0.005^{\mathrm{c}}$ & $26.63 \pm 3.49^{\mathrm{c}}$ & $29.65 \pm 0.21^{\mathrm{c}}$ & $25.39 \pm 1.85^{\mathrm{b}}$ \\
Root ethylacetate & $78.64 \pm 0.02^{\mathrm{g}}$ & $114.59 \pm 5.31^{\mathrm{h}}$ & $6.23 \pm 0.20^{\mathrm{ab}}$ & $120.38 \pm 4.01^{\mathrm{g}}$ \\
Root $<3.5 \mathrm{kDa}$ & $101.59 \pm 0.01^{\mathrm{i}}$ & $220.41 \pm 4.65^{\mathrm{k}}$ & $5.44 \pm 0.27^{\mathrm{a}}$ & $137.97 \pm 6.79^{\mathrm{h}}$ \\
Root $>3.5 \mathrm{kDa}$ & $103.40 \pm 0.01^{\mathrm{i}}$ & $120.71 \pm 3.44^{\mathrm{h}}$ & $7.05 \pm 0.48^{\mathrm{ab}}$ & $106.66 \pm 7.05^{\mathrm{f}}$ \\
Root Water & $72.53 \pm 0.02^{\mathrm{fg}}$ & $184.79 \pm 11.05^{\mathrm{i}}$ & $5.42 \pm 0.06^{\mathrm{a}}$ & $138.45 \pm 1.62^{\mathrm{h}}$ \\
\hline
\end{tabular}

${ }^{1}$ For all the values within a column, different letter superscripts mean significant differences $(P<0.05)$.

also the case in the present study. The antioxidant activity of methanolic extract of marula leaf has been reported to be higher or equal that of butylated hydroxytoluene [27, 29]. The present study has shown that the bark and root extracts had even higher antioxidant activity than the leaf extracts.

3.2. Analyses of Polyphenols by HPLC-ESI-MS/MS. The $<3.5 \mathrm{kDa}$ dialysed extracts that possessed the best antioxidant activity and phenolic content were selected for characterisation by HPLC-MS/MS. A total of 36 compounds were observed with 27 phenolic compounds being tentatively or fully identified, a disaccharide, four derivatives of either sugar or galloyl derivatives and four compounds could not be identified (Table 3). Structural characterisation of each compound was achieved through accurate mass measurement and interpretation of CID mass spectrum. Of the 36 compounds, the identities of 9 phenolic compounds, namely, gallic acid, catechin, epicatechin, epicatechin-3-O-gallate, epigallocatechin-3-Ogallate, quercetin-3-O-arabinoside, quercetin-3-O-rhamnoside, quercetin-3-O-glucoside, and procyanidin B2 were confirmed by the comparison with retention times of the standards.

The phenolic compounds present in the leaf, bark, and root of $S$. birrea differed from those reported in the fruit. For example, Ndhlala et al. reported the presence of caffeic acid, vanillic acid, ferulic acid, and $p$-coumaric acid in the peel and pulp of the fruit, none of which were detected in extracts from the plant tissues examined in the present study [16]. Galloyl derivatives of flavonoid glycosides and procyanidins were the common phenolic compounds in the marula plant. The flavonoid glycosides were exclusively found in the leaf extracts while the galloylated tannins were predominant in the bark extracts (Table 3 and Figure 1). Three previously unreported phenolic glycosides for this species, namely, dihydrobenzoic acid-O-pentoside, quercetin-3-Oarabinoside, kaempferol-O-pentoside, and hydroxyl benzoyl kaempferol-O-hexoside, were identified (Figure 2) in the leaf extract in addition to the eight compounds (peaks 12-15, $17-19,21)$ that had been previously reported [13]. Shown in the inserts of Figure 2 are the proposed chemical structures, cleavages during CID experiment, and the expected exact $\mathrm{m} / z$ values for the fragment ions of four compounds new to the marula plant. The accurate mass measurement of $m / z 285.1$ (peak 4) produced the elemental composition of the compound as $\mathrm{C}_{12} \mathrm{H}_{14} \mathrm{O}_{8}$. Subsequent MS/MS studies on the ions $\mathrm{m} / \mathrm{z} 285.1$ showed the major product ions $\mathrm{m} / \mathrm{z}$ 153.0 tentatively assigned as deprotonated dihydroxybenzoic acid (DHBA) from the loss of dehydrated pentose $(132 \mathrm{Da})$ and a further loss of $\mathrm{CO}_{2}$ generating the minor product ions $m / z$ 108.0. Accurate mass measurements on the product ions $\mathrm{m} / z 153.0$ and $\mathrm{m} / z 108.0$ fitted well with the empirical formula for DHBA and the decarboxylated DHBA, respectively (Figure 2(a)). The $m / z 433.1$ (peak 16) was initially assigned as quercetin- $O$-pentoside based on the accurate mass measurement and the loss of a dehydrated pentoside residue, which produced the product ion $\mathrm{m} / z$ 301.1 (deprotonated quercetin) in the MS/MS spectrum (Figure 2(b)); the identification was further supported by the identical retention time of the standard quercetin-3$O$-arabinoside. Similarly, the identification of kaempferol$O$-pentoside was reached for the $[\mathrm{M}-\mathrm{H}]^{-}$ion at $\mathrm{m} / z 417.1$ (peak 20) and upon its fragmentation, produced the product ion $\mathrm{m} / \mathrm{z}$ of 285.1 corresponding to kaempferol (or luteolin) via the loss of a dehydrated pentoside residue (Figure 2(c)). A hydroxyl benzoyl kaempferol-O-hexoside was assigned for peak 22 based on the accurate mass measurement and MS/MS fragmentation pattern (Figure 2(d)). It must be noted 
TABLE 3: Phytochemicals observed in HPLC-MS analysis of various parts of S. birrea.

\begin{tabular}{|c|c|c|c|c|c|c|}
\hline $\begin{array}{l}\text { Peak } \\
\text { nnmber }\end{array}$ & $\mathrm{RT}(\min )$ & Proposed compound ID & Empirical formula & Calculated $m / z$ & Observed $\mathrm{m} / \mathrm{z}$ & MS/MS ions \\
\hline 1 & 1.54 & Disaccharide & $\mathrm{C}_{12} \mathrm{H}_{21} \mathrm{O}_{11}{ }^{-}$ & 341.1084 & 341.1075 & $179.0,143.1,101.0$ \\
\hline 2 & 2.02 & Gallic acid ${ }^{* * *}$ & $\mathrm{C}_{7} \mathrm{H}_{5} \mathrm{O}_{5}^{-}$ & 169.0137 & 169.0126 & 125.0 \\
\hline 3 & 2.74 & Procyanidin dimer B2 & $\mathrm{C}_{30} \mathrm{H}_{25} \mathrm{O}_{12}{ }^{-}$ & 577.1346 & 577.1326 & $407.1,289.0,169.0,125.0$ \\
\hline $4^{* *}$ & 2.96 & $\begin{array}{l}\text { Dihydroxy benzoic acid } \\
\text { pentoside }\end{array}$ & $\mathrm{C}_{12} \mathrm{H}_{13} \mathrm{O}_{8}^{-}$ & 285.0610 & 285.0605 & 152.1/153.1, 108.1/109.1 \\
\hline 5 & 3.48 & $\begin{array}{l}\text { Monogalloylated } \\
\text { procyanidin dimer B } \\
\text { (P2G1) }\end{array}$ & $\mathrm{C}_{37} \mathrm{H}_{29} \mathrm{O}_{16}^{-}$ & 729.1456 & 729.1442 & $577.1,407.1,289.1,169.0$ \\
\hline 6 & 3.88 & $\begin{array}{l}\text { Benzyl alcohol } \\
\text { hexoside-pentoside }\end{array}$ & $\mathrm{C}_{18} \mathrm{H}_{25} \mathrm{O}_{10}^{-}$ & 401.1448 & 401.1454 & $301.0,269.1,161.1,101.0$ \\
\hline 7 & 4.57 & Hexose derivative & $\mathrm{C}_{20} \mathrm{H}_{31} \mathrm{O}_{10}^{-}$ & 431.1917 & 431.1924 & $269,153.1$ \\
\hline 8 & 4.66 & $\begin{array}{l}\text { Digalloylated procyanidin } \\
\text { B (P2G2) }\end{array}$ & $\mathrm{C}_{44} \mathrm{H}_{33} \mathrm{O}_{20}^{-}$ & 881.1565 & 881.1535 & $729.2,559.6,407.1,169.0$ \\
\hline 9 & 5.60 & Megastigmane hexoside & $\mathrm{C}_{26} \mathrm{H}_{35} \mathrm{O}_{12}^{-}$ & 539.2129 & 539.2111 & $491.2,329.2,165.1$ \\
\hline 10 & 6.28 & Megastigmane hexoside & $\mathrm{C}_{26} \mathrm{H}_{35} \mathrm{O}_{12}^{-}$ & 539.2129 & 539.2123 & $491.2,329.2,165.1$ \\
\hline 11 & 7.34 & $\begin{array}{l}\text { Epicatechin 3-O-gallate } \\
(\mathrm{P} 1 \mathrm{G} 1)^{* * *}\end{array}$ & $\mathrm{C}_{22} \mathrm{H}_{17} \mathrm{O}_{10}^{-}$ & 441.0822 & 441.083 & $289.1,169.0$ \\
\hline $12^{*}$ & 8.20 & $\begin{array}{l}\text { Quercetin 3-O- } \beta \text {-D-(6" } \\
\text { galloyl)glucopyranoside }\end{array}$ & $\mathrm{C}_{28} \mathrm{H}_{23} \mathrm{O}_{16}^{-}$ & 615.0986 & 615.0982 & $463.2,301.1$ \\
\hline $13^{*}$ & 8.57 & $\begin{array}{l}\text { Quercetin 3-O- } \beta \text {-D- }\left(6^{\prime \prime}-\right. \\
\text { galloyl)galactopyranoside }\end{array}$ & $\mathrm{C}_{28} \mathrm{H}_{23} \mathrm{O}_{16}^{-}$ & 615.0986 & 615.0982 & $463.2,301.1$ \\
\hline $14^{*}$ & 9.37 & $\begin{array}{l}\text { Myricetin 3-O- } \alpha-\mathrm{L}- \\
\text { rhamnopyranoside }\end{array}$ & $\mathrm{C}_{21} \mathrm{H}_{19} \mathrm{O}_{12}^{-}$ & 463.0877 & 463.0877 & 301.1 \\
\hline $15^{*}$ & 9.63 & $\begin{array}{l}\text { Quercetin 3-O- } \beta \text {-D- } \\
\text { glucopyranoside*** }\end{array}$ & $\mathrm{C}_{21} \mathrm{H}_{19} \mathrm{O}_{12}{ }^{-}$ & 463.0877 & 463.0887 & 301.1 \\
\hline $16^{* *}$ & 10.11 & $\begin{array}{l}\text { Quercetin } \\
\text { 3-O-arabinoside }{ }^{* * *}\end{array}$ & $\mathrm{C}_{20} \mathrm{H}_{17} \mathrm{O}_{11}^{-}$ & 433.0771 & 433.0776 & 301.1 \\
\hline $17^{*}$ & 10.53 & $\begin{array}{l}\text { Kaempferol 3-O- } \beta \text {-D- }\left(6^{\prime \prime} \text { - }\right. \\
\text { galloyl)glucopyranoside }\end{array}$ & $\mathrm{C}_{28} \mathrm{H}_{23} \mathrm{O}_{15}^{-}$ & 599.1037 & 599.1041 & $447.1,313.1,285.1,169.0$ \\
\hline $18^{*}$ & 11.03 & $\begin{array}{l}\text { Quercetin 3-O- } \alpha \text {-L- } \\
\text { rhamnopyranoside*** }\end{array}$ & $\mathrm{C}_{21} \mathrm{H}_{19} \mathrm{O}_{11}^{-}$ & 447.0928 & 447.0941 & $301.1 / 300.0,285.1 / 284.1$ \\
\hline $19^{*}$ & 11.36 & $\begin{array}{l}\text { Quercetin 3-O- } \alpha-\left(5^{\prime \prime}-\right. \\
\text { galloyl)arabinofuranoside }\end{array}$ & $\mathrm{C}_{27} \mathrm{H}_{21} \mathrm{O}_{15}^{-}$ & 585.0881 & 585.0876 & $433.1,301.1$ \\
\hline $20^{* *}$ & 11.60 & Kaempferol pentoside & $\mathrm{C}_{20} \mathrm{H}_{17} \mathrm{O}_{10}{ }^{-}$ & 417.0822 & 417.0838 & $285.1 / 284.0$ \\
\hline $21^{*}$ & 12.36 & $\begin{array}{l}\text { Kaempferol 3-O- } \alpha \text {-L- } \\
\text { rhamnopyranoside }\end{array}$ & $\mathrm{C}_{21} \mathrm{H}_{19} \mathrm{O}_{10}^{-}$ & 431.0978 & 431.0975 & 285.1 \\
\hline $22^{* *}$ & 12.61 & $\begin{array}{l}\text { Hydroxy benzoyl } \\
\text { kaempferol-O-hexoside }\end{array}$ & $\mathrm{C}_{28} \mathrm{H}_{23} \mathrm{O}_{13}^{-}$ & 567.1139 & 567.1148 & $447.1,285.0,255.0,137.0$ \\
\hline 23 & 12.99 & Galloyl hexoside derivative & $\mathrm{C}_{26} \mathrm{H}_{35} \mathrm{O}_{11}^{-}$ & 523.2179 & 523.2172 & $361.2,313.1,169.0$ \\
\hline 24 & 2.38 & Pentoside derivative & $\mathrm{C}_{20} \mathrm{H}_{29} \mathrm{O}_{12}^{-}$ & 461.1659 & 461.1653 & $329.1,191.1,179.1,149.1$ \\
\hline 25 & 2.79 & Catechin $^{* * *}$ & $\mathrm{C}_{15} \mathrm{H}_{13} \mathrm{O}_{6}^{-}$ & 289.0712 & 289.0700 & \\
\hline 26 & 3.12 & $\begin{array}{l}\text { Galloylepicatechin- } \\
\text { epigallocatechin-3-O- } \\
\text { gallate }\end{array}$ & $\mathrm{C}_{44} \mathrm{H}_{33} \mathrm{O}_{21}^{-}$ & 897.1514 & 897.1510 & $449.1,407.1,289.1,177.0,125.1$ \\
\hline 27 & 3.35 & $\begin{array}{l}\text { Epigallocatechin } \\
3-O \text {-gallate*** }\end{array}$ & $\mathrm{C}_{22} \mathrm{H}_{17} \mathrm{O}_{11}^{-}$ & 457.0771 & 457.0763 & 305.1 \\
\hline 28 & 3.75 & Epicatechin $^{* * *}$ & $\mathrm{C}_{15} \mathrm{H}_{13} \mathrm{O}_{6}^{-}$ & 289.0712 & 289.0700 & \\
\hline 29 & 4.95 & $\begin{array}{l}\text { Trigalloylated procyanidin } \\
\text { trimer (P3G3) }\end{array}$ & $\mathrm{C}_{66} \mathrm{H}_{50} \mathrm{O}_{30}^{-}$ & 1321.2309 & 1321.237 & $1169.3,1017.3,881.1,577.1,407.0,169.0$ \\
\hline 30 & 5.47 & Unknown & $\mathrm{C}_{21} \mathrm{H}_{19} \mathrm{O}_{17}^{-}$ & 543.0622 & 543.0618 & \\
\hline 31 & 8.04 & $\begin{array}{l}\text { Epicatechin-O-gallate } \\
\text { (P1G1) }\end{array}$ & $\mathrm{C}_{22} \mathrm{H}_{17} \mathrm{O}_{10}^{-}$ & 441.0822 & 441.083 & $289.1,169.0$ \\
\hline
\end{tabular}


TABle 3: Continued.

\begin{tabular}{|c|c|c|c|c|c|c|}
\hline $\begin{array}{l}\text { Peak } \\
\text { nnmber }\end{array}$ & $\mathrm{RT}(\min )$ & Proposed compound ID & Empirical formula & Calculated $m / z$ & Observed $m / z$ & MS/MS ions \\
\hline 32 & 9.37 & Unknown & $\mathrm{C}_{13} \mathrm{H}_{7} \mathrm{O}_{8}^{-}$ & 291.0141 & 291.015 & \\
\hline 33 & 10.49 & $\begin{array}{l}\text { Digalloylated procyanidin } \\
\text { dimer B (P2G2) }\end{array}$ & $\mathrm{C}_{44} \mathrm{H}_{33} \mathrm{O}_{20}^{-}$ & 881.1565 & 881.1577 & $729.2,559.6,407.1,169.0$ \\
\hline 34 & 10.84 & Unknown & $\mathrm{C}_{16} \mathrm{H}_{23} \mathrm{O}_{14}{ }^{-}$ & 439.1088 & 439.1078 & \\
\hline 35 & 14.67 & Unknown & $\mathrm{C}_{19} \mathrm{H}_{17} \mathrm{O}_{7}^{-}$ & 357.0975 & 357.084 & \\
\hline 36 & 3.56 & Galloyl derivative & $\mathrm{C}_{20} \mathrm{H}_{21} \mathrm{O}_{12}^{-}$ & 453.1033 & 453.104 & $313.0,169.0$ \\
\hline
\end{tabular}

*Identified based on previous report by Braca et al. 2003 [13].

*** Previously unreported in Sclerocarya birrea.

*** Identification by comparison with standards.

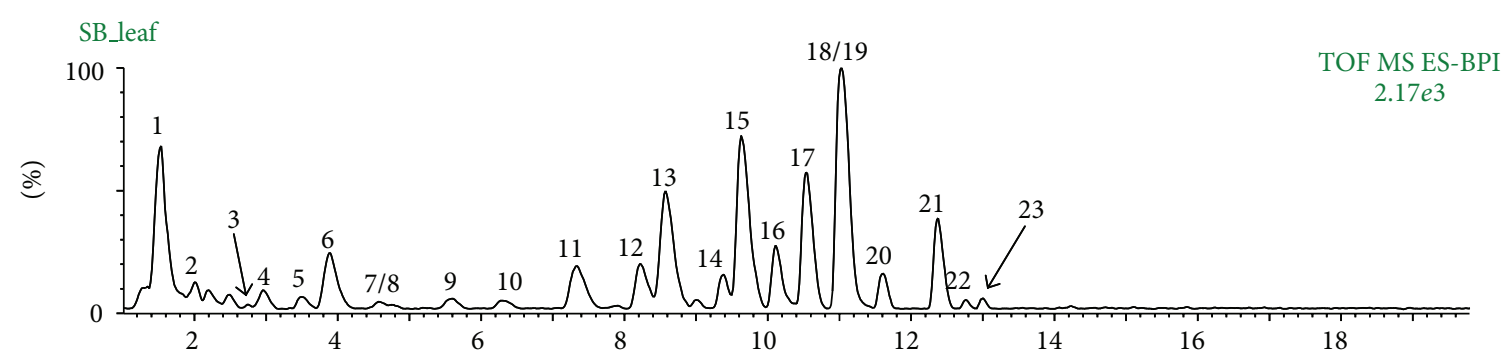

(a)

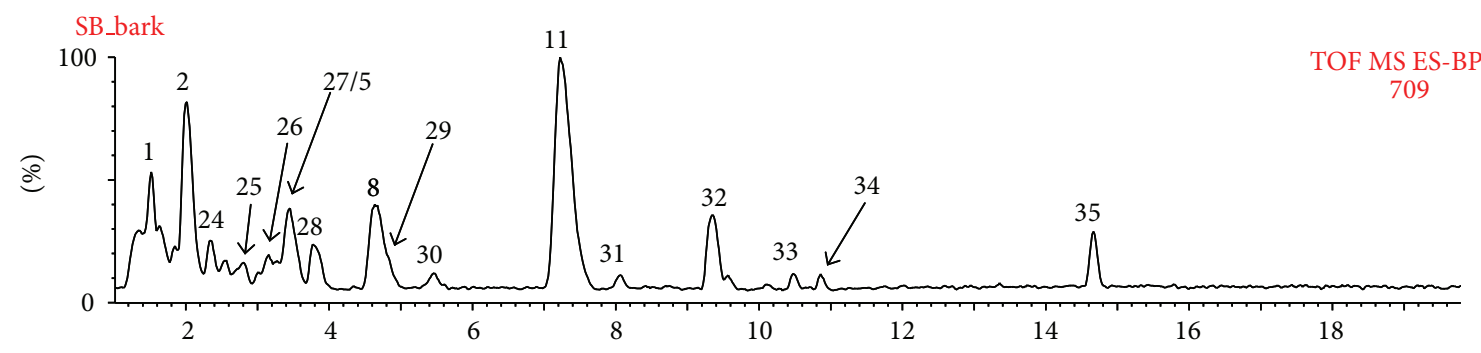

(b)

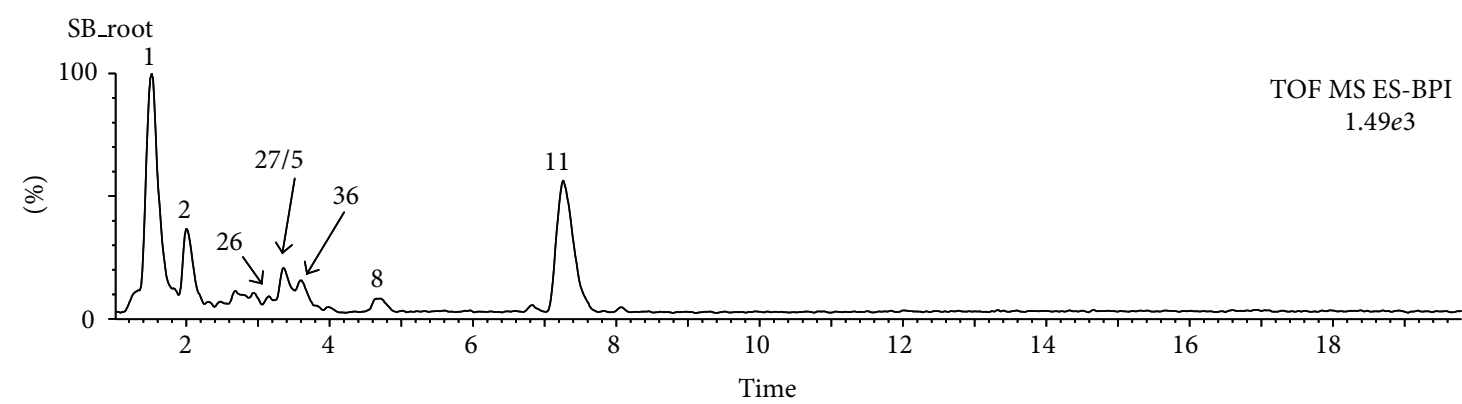

(c)

FIGURE 1: HPLC chromatograms showing the phytochemicals in (a) leaf extract, (b) bark extract, and (c) root extract of $S$. birrea.

that kaempferol has an identical chemical formula to that of luteolin but they are structurally different and hence produces different fragment ions [30]. Kaempferol, unlike luteolin, has been shown to lose $30 \mathrm{Da}$ neutral molecule resulting in a product ion $m / z 255$ which was also seen in the MS/MS spectra of peak 20 and peak 22 (Figures 2(c) and 2(d)), thus confirming these two peaks were kaempferol derivatives. This approach was taken to identification of megastigmane hexosides (peaks 9 and 10) and benzyl-alcohol hexosidepentoside (peak 6). Our findings are in congruent with the reports in the past where benzyl derived phytochemicals had been commonly seen in the marula fruit pulp and the whole fruit [31].

Procyanidins, a group of flavonoids ubiquitous in the plant kingdom, are a mixture of flavan-3-ol monomers (epicatechin and/or catechin) commonly bonded through C4-C8 


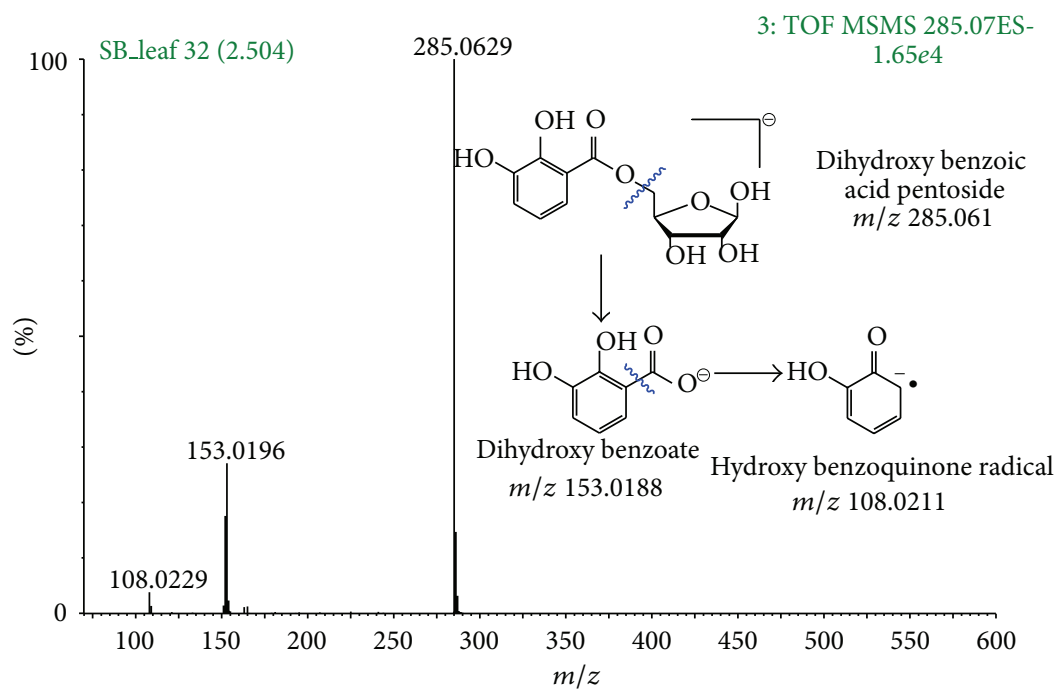

(a)

TOF MSMS 433.09ES-

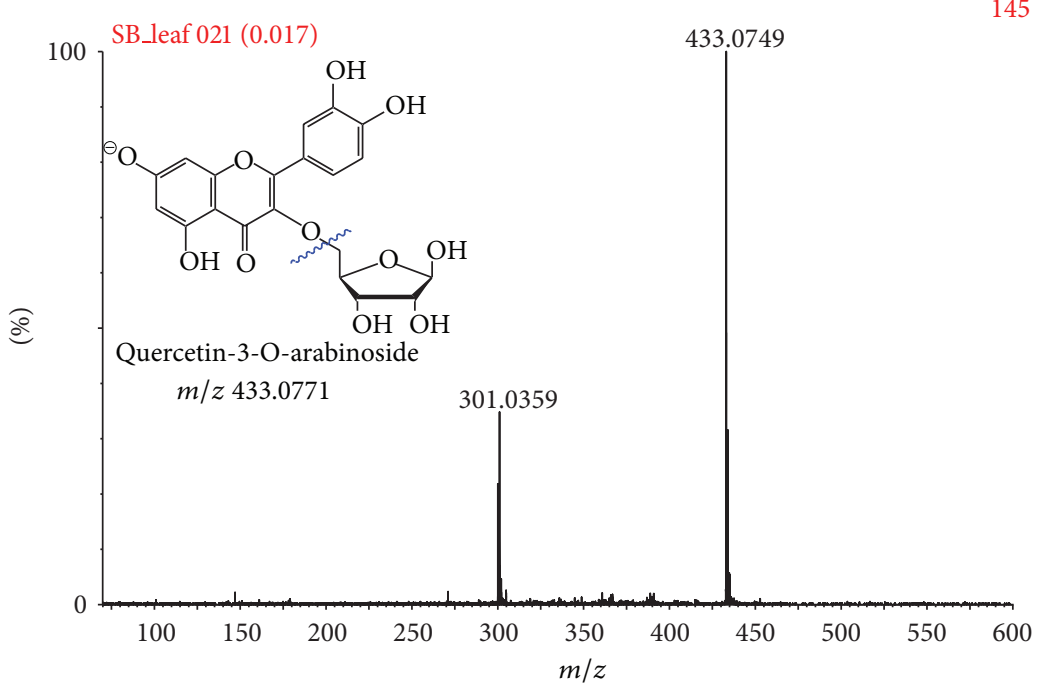

(b)

6: TOF MSMS 417.09ES-

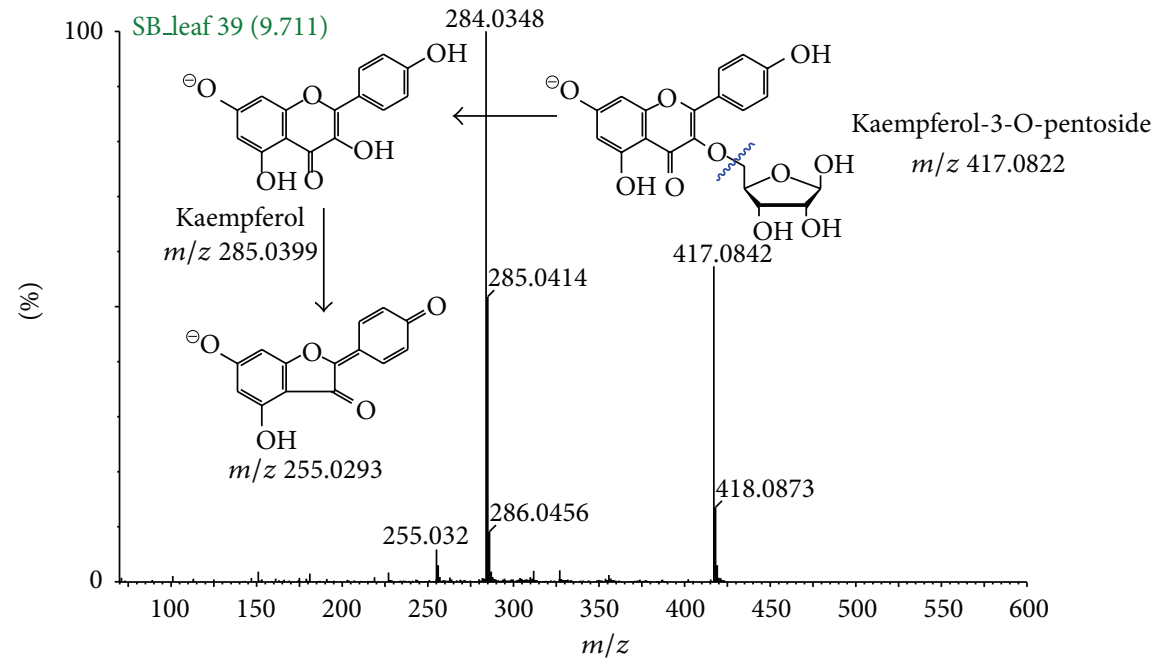

(c)

Figure 2: Continued. 


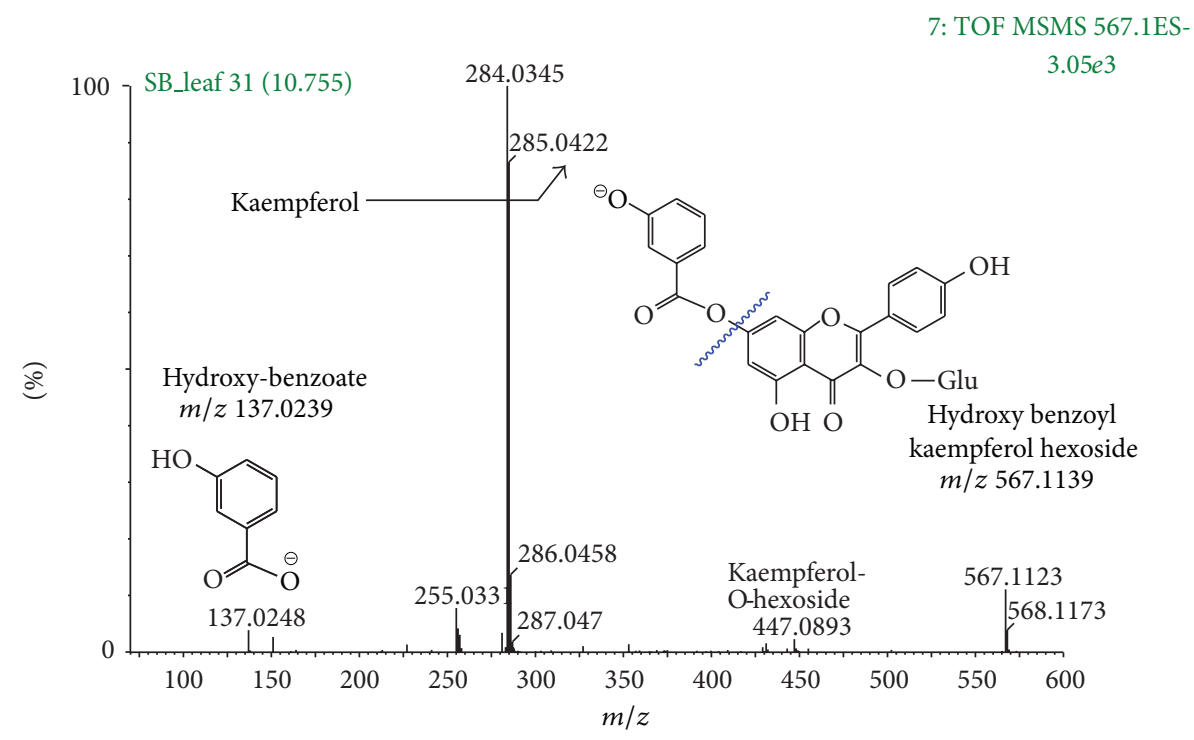

(d)

FIGURE 2: ESI-MS/MS spectra of four polyphenolic glycosides reported for the first time in the S. birrea: (a) dihydroxybenzoic acid-Opentoside (peak 4), (b) quercetin-3-O-arabinoside (peak 16), (c) kaempferol-O-pentoside (peak 20), and (d) hydroxyl benzoyl kaempferol$O$-hexoside (peak 22).

linkages. The procyanidins were predominantly found in the bark of S. birrea (Figure 1). Epicatechin-3-O-gallate (ECG) in this study was found in the water part of the partitioned of the methanolic extract in contrast to previous report on its occurrence in the ethylacetate portion of a methanolic extract from the marula bark [20]. Another compound (peak 31) with identical molecular mass and fragment ions as that of ECG but in less abundance was observed in the bark and root extracts; this compound was assigned as an isomer of epicatechin-3-O-gallate. Most of the procyanidins were esterified with gallic acid residues and produced polymers of varying molecular mass (Table 3 ). The largest galloylated procyanidin polymer was found with a molecular mass of $1322 \mathrm{Da}$ (peak 29) with a degree of galloylation of 3 and was identified as trigalloylated procyanidin trimer (P3G3). Lower degrees of galloylated procyanidins such as P3G2 at $\mathrm{m} / \mathrm{z} 881.2$ (peaks 8, 33), P2G1 at $\mathrm{m} / z 729.2$ (peak 5) were also found largely in the bark and root extracts. Further HPLC-ESI-MS/MS data supported the diagnosis where the sequential loss of neutral molecules due to the loss of the dehydrated gallic acid residue $(152 \mathrm{Da})$ and the elimination of an epicatechin unit $(288 \mathrm{Da})$ produced the major product ions from the galloylated procyanidins as shown in Figure 3. Although several previous studies have shown the presence of procyanidins and their galloyl derivatives in marula, this report profiles the presence of an additional 6 procyanidins (Table 3). A variety of these types of procyanidin derivatives have also been reported previously in both grape seeds and pomace [32,33]. In many cases a range of different structures and isomers of procyanidins would be present that currently would not be detectable using HPLC-MS due to inability to separate and elute them from an HPLC column and due to the lack of sensitivity based on the small quantities that would be present for each particular structure.

As evident from this study, flavonoid glycosides and galloylated procyanidins constituted the bulk of phenolic compounds in the $<3.5 \mathrm{kDa}$ fractions. The only previous report on the phenolic composition of the bark identified one epicatechin derivative. The present study is also the first to report on the phenolic composition of root extracts from this commercially important tree and they contain a mixture of mostly epicatechin and gallic acid derivatives. Epicatechin-3$O$-gallate has been shown to illicit secretagogue activity when derived from the bark of the plant [20]. The procyanidins were mainly found in roots and barks with high phenolic contents and were thus responsible for the high antioxidant activity. Previous studies have shown that the procyanidins also possess antiviral and anticancer properties but limited antimicrobial activity [34].

\section{Conclusion}

Application of HPLC-MS/MS technique provided useful information to characterize 27 phenolic compounds in the extracts of marula. The accurate mass measurements and fragments produced during CID are the diagnostic features of these compounds which could be used to identify them in different extracts. Four phenolic glycosides and 6 procyanidins have been reported for the first time in marula. Further spectroscopic characterization, specifically NMR, will be required to establish the identity of the glycoside and underpin the position of its linkage to the flavonoid ring. However, due to small amount of sample material, this could not be carried out in this present study. The antioxidant 


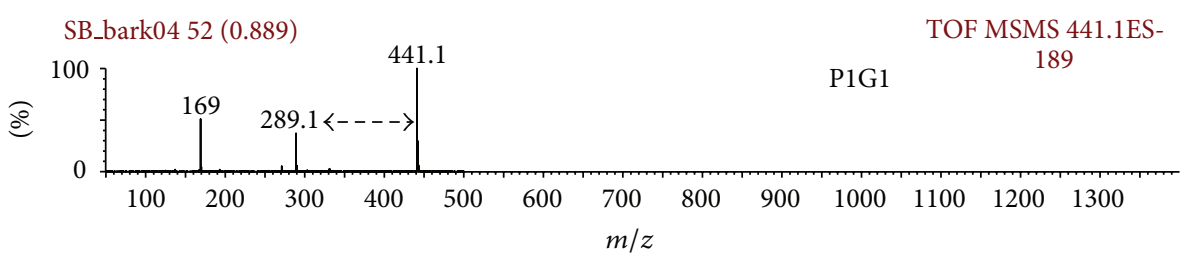

(a)

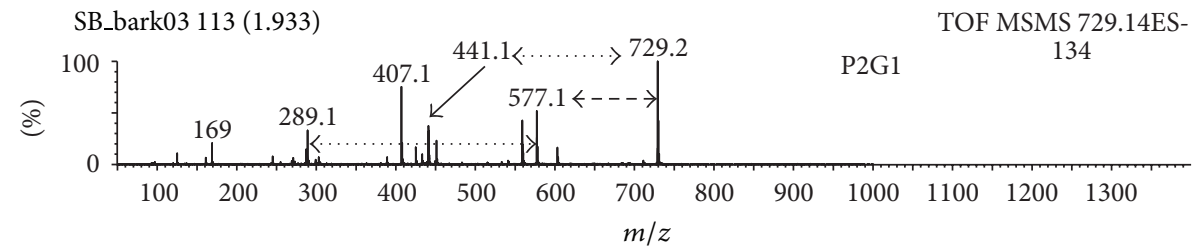

(b)

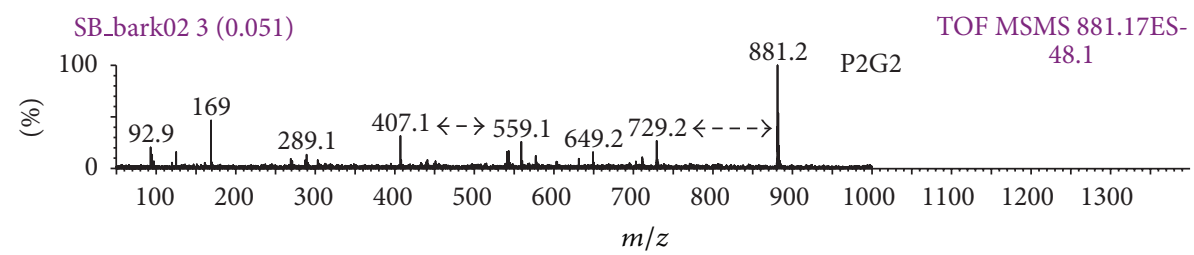

(c)

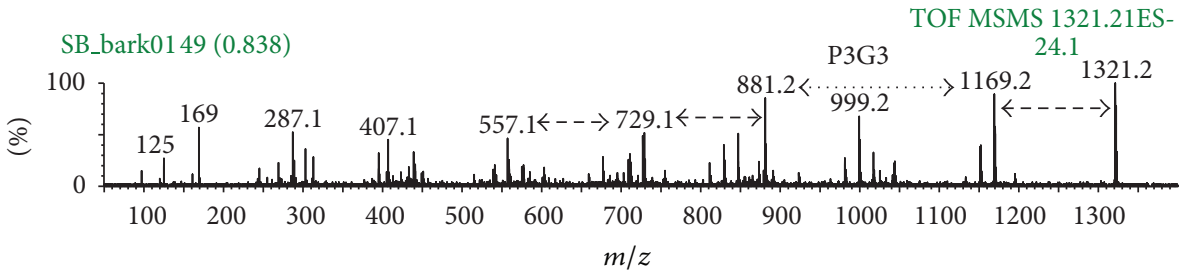

(d)

FIGURE 3: ESI-MS/MS spectra of various oligomers of galloylated procyanidins: (a) monogalloylated procyanidin or P1G1 (peaks 11 and 31), (b) monogalloylated procyanidin dimer B or P2G1 (peak 5); (c) digalloylated procyanidin dimer B or P2G2 (peaks 8 and 33), and (d) trigalloylated procyanidin trimer C or P3G3 (peak 29). The loss of galloyl residue (152 Da) is illustrated with dashed arrow while the elimination of the epicatechin unit $(288 \mathrm{Da})$ is represented with dotted arrow.

activities of the extracts were linked to the occurrence of moderate to highly polar polyphenols particularly flavonoid glycosides.

\section{Conflict of Interests}

There is no conflict of interests.

\section{Acknowledgments}

The authors thank Professor Valeria Costantino of the University of Napoli, Italy, for her support and encouragement towards this project. They have been most grateful for the financial support from the Irish Phytochemical Food Network (IPFN) which is funded under Food Institutional Research Measure (FIRM) by the Irish Department of Agriculture, Food and Marine.

\section{References}

[1] C. R. Peter, "Notes on the distribution and relative abundance of Sclerocarya birrea (A. Rich) Hochst. (Anacardiaceae)," Monographs in Systematic Botany of the Missouri Botanical Gardens, vol. 25, pp. 403-410, 1988.

[2] G. N. Gouwakinnou, A. M. Lykke, A. E. Assogbadjo, and B. Sinsin, "Local knowledge, pattern and diversity of use of Sclerocarya birrea," Journal of Ethnobiology and Ethnomedicine, vol. 7, article 8, 2011.

[3] R. Wynberg, J. Cribbins, R. Leakey et al., "Knowledge on Sclerocarya birrea subsp. caffra with emphasis on its importance as a non-timber forest product in South and southern Africa: a summary. Part 2: commercial use, tenure and policy, domestication, intellectual property rights and benefit-sharing," Southern African Forestry Journal, no. 196, pp. 67-77, 2002.

[4] B. A. Jama, A. M. Mohamed, J. Mulatya, and A. N. Njui, "Comparing the "Big Five": a framework for the sustainable management of indigenous fruit trees in the drylands of East 
and Central Africa," Ecological Indicators, vol. 8, no. 2, pp. 170$179,2008$.

[5] N. C. Mokgolodi, Y.-F. Ding, M. P. Setshogo, C. Ma, and Y. J. Liu, "The importance of an indigenous tree to southern African communities with specific relevance to its domestication and commercialization: a case of the marula tree," Forestry Studies in China, vol. 13, no. 1, pp. 36-44, 2011.

[6] M. Gelfand, The Traditional Medical Practitioner in Zimbabwe: His Principles of Practice and Pharmacopoeia, Mambo Press, 1985.

[7] J. A. O. Ojewole, T. Mawoza, W. D. H. Chiwororo, and P. M. O. Owira, "Sclerocarya birrea (A. Rich) Hochst. ["Marula"] (anacardiaceae): a review of its phytochemistry, pharmacology and toxicology and its ethnomedicinal uses," Phytotherapy Research, vol. 24, no. 5, pp. 633-639, 2010.

[8] J. N. Eloff, "Antibacterial activity of Marula (Sclerocarya birrea (A. rich.) Hochst. subsp. Caffra (Sond.) Kokwaro) (Anacardiaceae) bark and leaves," Journal of Ethnopharmacology, vol. 76, no. 3, pp. 305-308, 2001.

[9] P. Masoko, T. J. Mmushi, M. M. Mogashoa, M. P. Mokgotho, L. J. Mampuru, and R. L. Howard, "In vitro evaluation of the antifungal activity of Sclerocarya birrea extracts against pathogenic yeasts," African Journal of Biotechnology, vol. 7, no. 20, pp. 3521-3526, 2008.

[10] L. J. McGaw, D. Van der Merwe, and J. N. Eloff, "In vitro anthelmintic, antibacterial and cytotoxic effects of extracts from plants used in South African ethnoveterinary medicine," Veterinary Journal, vol. 173, no. 2, pp. 366-372, 2007.

[11] I. G. M. Ndifossap, F. Frigerio, M. Casimir et al., "Sclerocarya birrea (Anacardiaceae) stem-bark extract corrects glycaemia in diabetic rats and acts on $\beta$-cells by enhancing glucosestimulated insulin secretion," Journal of Endocrinology, vol. 205, no. 1, pp. 79-86, 2010.

[12] H. Borochov-Neori, S. Judeinstein, A. Greenberg et al., "Phenolic antioxidants and antiatherogenic effects of marula (Sclerocarrya birrea subsp. caffra) fruit juice in healthy humans," Journal of Agricultural and Food Chemistry, vol. 56, no. 21, pp. 9884-9891, 2008.

[13] A. Braca, M. Politi, R. Sanogo et al., "Chemical composition and antioxidant activity of phenolic compounds from wild and cultivated Sclerocarya birrea (Anacardiaceae) leaves," Journal of Agricultural and Food Chemistry, vol. 51, no. 23, pp. 6689-6695, 2003.

[14] A. Lamien-Meda, C. E. Lamien, M. M. Y. Compaoré et al., "Polyphenol content and antioxidant activity of fourteen wild edible fruits from Burkina Faso," Molecules, vol. 13, no. 3, pp. 581-594, 2008.

[15] A. A. Mariod, B. Matthäus, and I. H. Hussein, "Antioxidant properties of methanolic extracts from different parts of Sclerocarya birrea," International Journal of Food Science and Technology, vol. 43, no. 5, pp. 921-926, 2008.

[16] A. R. Ndhlala, A. Kasiyamhuru, C. Mupure, K. Chitindingu, M. A. Benhura, and M. Muchuweti, "Phenolic composition of Flacourtia indica, Opuntia megacantha and Sclerocarya birrea," Food Chemistry, vol. 103, no. 1, pp. 82-87, 2007.

[17] N. P. Brunton, D. A. Cronin, and F. J. Monahan, "Volatile components associated with freshly cooked and oxidized offflavours in Turkey breast meat," Flavour and Fragrance Journal, vol. 17, no. 5, pp. 327-334, 2002.
[18] M. N. O’Grady, F. J. Monahan, and N. P. Brunton, "Oxymyoglobin oxidation and lipid oxidation in bovine musclemechanistic studies," Journal of Food Science, vol. 66, no. 3, pp. 386-392, 2001.

[19] P. B. Addis, "Occurrence of lipid oxidation products in foods," Food and Chemical Toxicology, vol. 24, no. 10-11, pp. 1021-1030, 1986.

[20] J. Galvez Peralta, A. Zarzuelo, R. Busson, C. Cobbaert, and P. De Witte, "(-)-Epicatechin-3-galloyl ester: a secretagogue compound from the bark of Sclerocarya birrea," Planta Medica, vol. 58, no. 2, pp. 174-175, 1992.

[21] A. A. Aganga and K. W. Mosase, "Tannin content, nutritive value and dry matter digestibility of Lonchocarpus capassa, Zizyphus mucronata, Sclerocarya birrea, Kirkia acuminata and Rhus lancea seeds," Animal Feed Science and Technology, vol. 91, no. 1-2, pp. 107-113, 2001.

[22] T. Ariga and M. Hamano, "Radical scavenging action and its mode in Procyanidins B-1 and B-3 from azuki beans to peroxyl radicals (Food \& Nutrition)," Agricultural and Biological Chemistry, vol. 54, no. 10, pp. 2499-2504, 1990.

[23] G. E. Arteel and H. Sies, "Protection against peroxynitrite by cocoa polyphenol oligomers," FEBS Letters, vol. 462, no. 1-2, pp. 167-170, 1999.

[24] P. Goupy, M. Hugues, P. Boivin, and M. J. p. Amiot, "Antioxidant composition and activity of barley (Hordeum vulgare) and malt extracts and of isolated phenolic compounds," Journal of the Science of Food and Agriculture, vol. 79, no. 12, pp. 1625-1634, 1999.

[25] P. Stratil, B. Klejdus, and V. Kubáň, "Determination of total content of phenolic compounds and their antioxidant activity in vegetables-evaluation of spectrophotometric methods," Journal of Agricultural and Food Chemistry, vol. 54, no. 3, pp. 607616, 2006.

[26] V. L. Singleton, R. Orthofer, and R. M. Lamuela-Raventós, "Analysis of total phenols and other oxidation substrates and antioxidants by means of folin-ciocalteu reagent," Methods in Enzymology, vol. 299, pp. 152-178, 1998.

[27] M. Moyo, A. R. Ndhlala, J. F. Finnie, and J. Van Staden, "Phenolic composition, antioxidant and acetylcholinesterase inhibitory activities of Sclerocarya birrea and Harpephyllum caffrum (Anacardiaceae) extracts," Food Chemistry, vol. 123, no. 1, pp. 69-76, 2010.

[28] J. Pérez-Jiménez and F. Saura-Calixto, "Literature data may underestimate the actual antioxidant capacity of cereals," Journal of Agricultural and Food Chemistry, vol. 53, no. 12, pp. 50365040, 2005.

[29] P. Olsen, O. Meyer, N. Bille, and G. Wurtzen, "Carcinogenicity study on butylated hydroxytoluene (BHT) in Wistar rats exposed in utero," Food and Chemical Toxicology, vol. 24, no. 1, pp. 1-12, 1986.

[30] M. Ye, Y. Yan, and D. A. Guo, "Characterization of phenolic compounds in the Chinese herbal drug Tu-Si-Zi by liquid chromatography coupled to electrospray ionization mass spectrometry," Rapid Communications in Mass Spectrometry, vol. 19, no. 11, pp. 1469-1484, 2005.

[31] A. M. Viljoen, G. P. P. Kamatou, and K. H. C. Başer, "Head-space volatiles of marula (Sclerocarya birrea subsp. caffra)," South African Journal of Botany, vol. 74, no. 2, pp. 325-326, 2008.

[32] C. P. Passos, S. M. Cardoso, M. R. M. Domingues, P. Domingues, C. M. Silva, and M. A. Coimbra, "Evidence for galloylated typeA procyanidins in grape seeds," Food Chemistry, vol. 105, no. 4, pp. 1457-1467, 2007. 
[33] I. I. Rockenbach, E. Jungfer, C. Ritter, B. Thiele, R. Fett, and R. Galensa, "Characterization of flavan-3-ols in seeds of grape pomace by CE, HPLC-DAD-MS and LC-ESI-FTICR-MS," Food Research International, vol. 48, pp. 848-855, 2012.

[34] T. De Bruyne, L. Pieters, M. Witvrouw, E. De Clercq, D. V. Berghe, and A. J. Vlietinck, "Biological evaluation of proanthocyanidin dimers and related polyphenols," Journal of Natural Products, vol. 62, no. 7, pp. 954-958, 1999. 

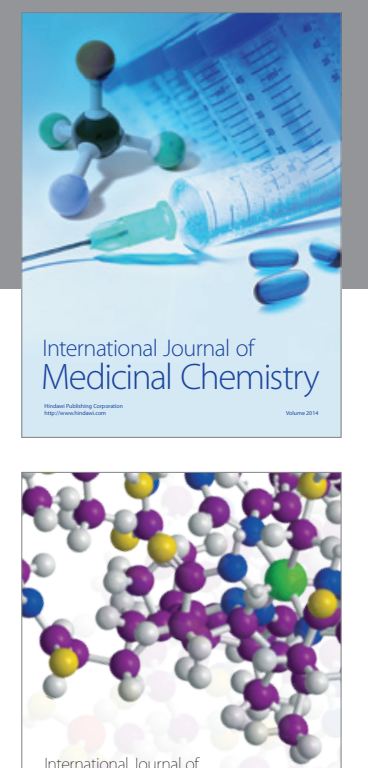

\section{Carbohydrate} Chemistry

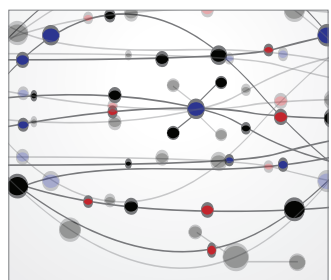

The Scientific World Journal
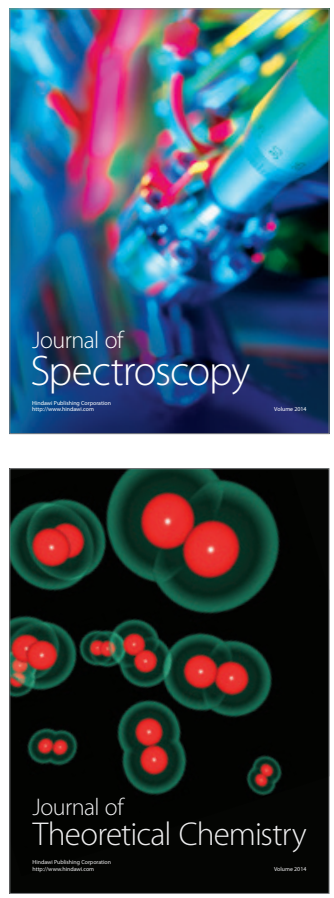
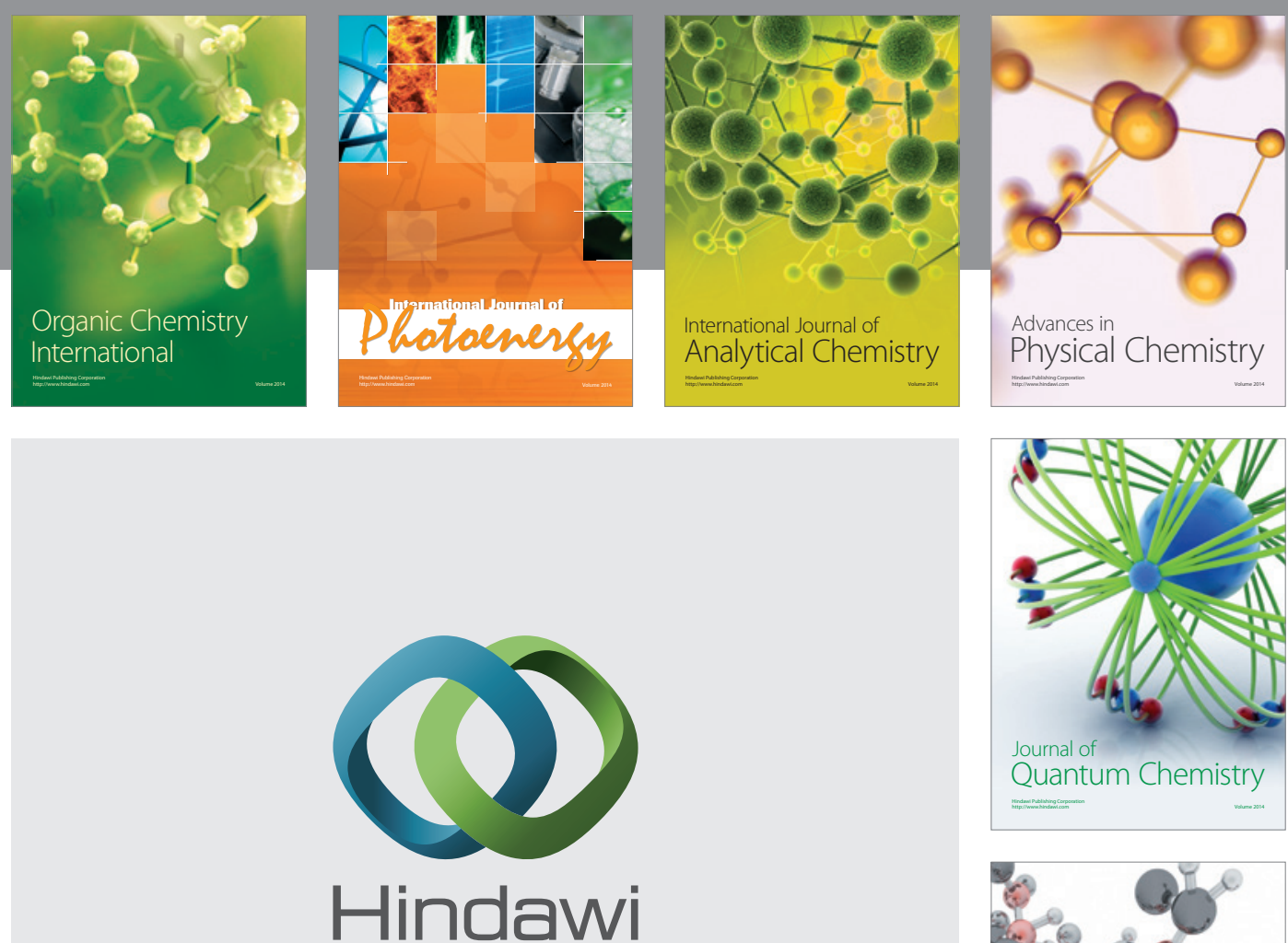

Submit your manuscripts at

http://www.hindawi.com

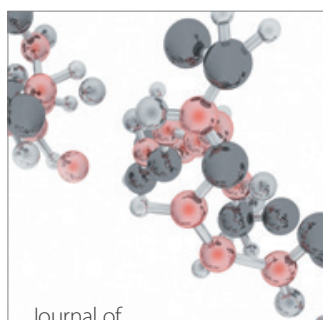

Analytical Methods

in Chemistry

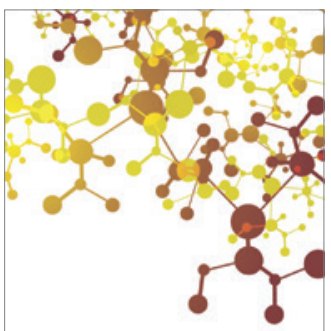

Journal of

Applied Chemistry

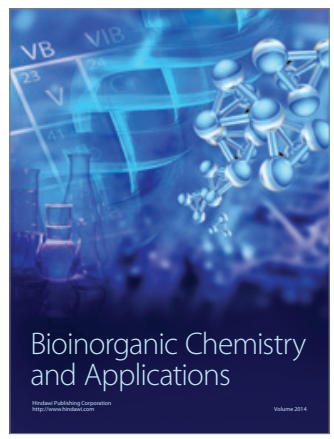

Inorganic Chemistry
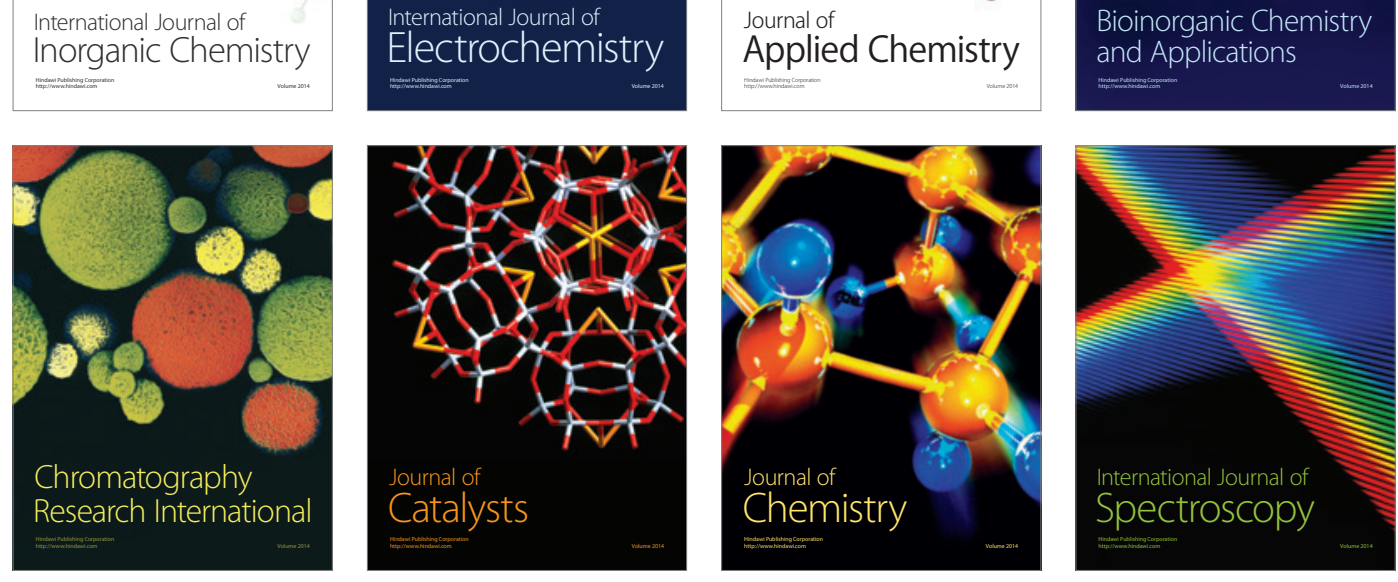